\title{
気象庁メソ数値予報モデル（MSM）GPVの 危機管理型防災対策への利用可能性 APPLICABILITY OF JMA-MSM-GPV TO RIVER BASIN RISK MANAGEMENT AND DISASTER MEASURES
}

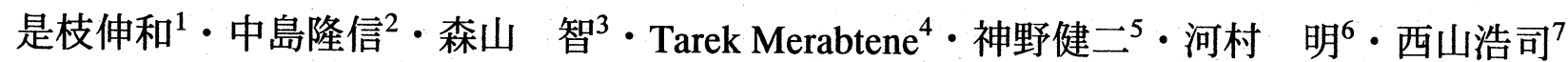 \\ Nobukazu KOREEDA, Takanobu NAKASHIMA, Satoshi MORIYAMA, Tarek MERABTENE, \\ Kenji JINNO, Akira KAWAMURA, Koji NISHIYAMA

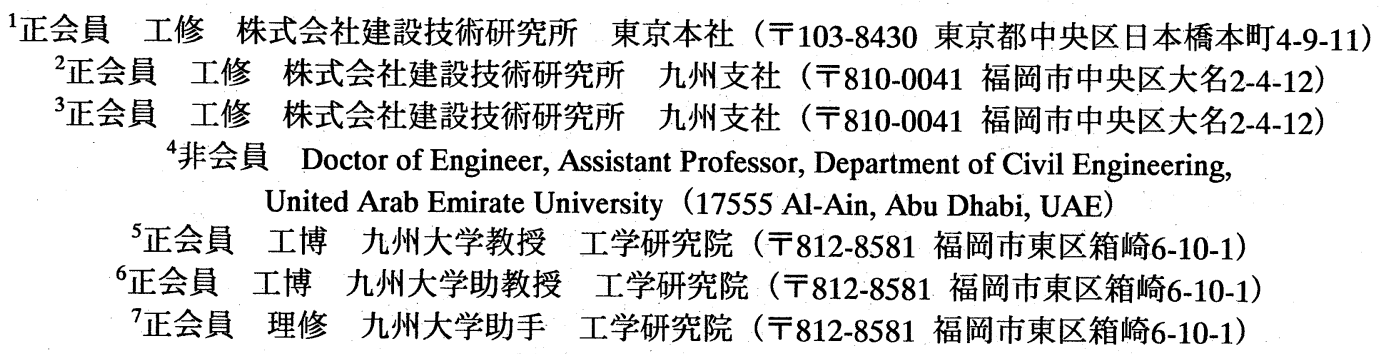

In recent years the economical conditions and the rising public criticism against large-scale public works represent the key issue toward the new directions of flood management in Japan. In consequence the future flood actions is shifting from the well known "traditional hard protection measures stating that no flood should occur" to the so called "soft countermeasures" stating that larger efforts should be concentrated on new alternatives aiming to reduce the loss of life and damage of important properties when a natural flood does occur. Therefore, under this new shift it becomes a primary issue to improve the current soft abilities to forecast the size and impact of flood disaster before a flood does occur. The present research is a growing assessment tool that aims to provide valuable decision support information likely to enhance the judgment abilities of river managers in providing disaster countermeasures actions such as refuge guidance. At earlier stage of this study the correlation nature between the actual AMeDAS precipitation data and the 6-hour forecast precipitation results of the Japan Meteorological Agency mesoscale numerical weather prediction model (Meso Spectral Model : MSM) was investigated. The results showed that rainfall forecast by MSM model would still need further research and improvement in order to be used in practice. At a second stage, the MSM climatological data where used to derive new output variables (such as water divergence) by applying a straightforward mathematical transformation model. The correlation results between the actual AMeDAS precipitation data and the transformed output variables were relatively high and promising.

\section{Key Words : MSM-GPV, AMeDAS, Condensed Water, Convective Adjustment}

\section{1.はじめに}

我が国では，これまで, 頻発する洪水に対し，河道改 修による河道の洪水通水能力の増大やダム・遊水地等の 建設による流域の洪水貯留能力の増大等を中心とした ハード施設整備が進められ, その結果, 着実な治水安全 度の向上が図られてきた. しかしながら, 福岡や東京, 名古屋等を襲った都市型水害等, 近年になってもなお,
洪水による被害はなくなっておらず, そのため, 今後も 継続してハード施設の整備を進めていく必要がある.

一方，我が国の財政状況や国民の大規模公共事業に対 する監視の目の厳しさ等, 公共事業を取り巻く環境も大 きく変化してきており, 今後, これまでのような早期の ハード施設整備は期待できないのが実情である. また, 例えハード施設が整備されたとしても, その施設計画規 模以上のインパクトがもたらされる可能性を常に内在し ており,これらのことから, 安価でかつ即効性のある対 
策の実現が急務となっている.

このような背景を踏まえ，我が国では，これまでの ハード施設整備と併せてソフト的な対策を講じることに より, 万が一災害が発生したとしても, 最低限人命や重 要資産は守ることを目的とした『危機管理型防災対策』 が推進されている.

本研究は，この危機管理型防災対策の重要な初期情報 となる降水量の予測に着目し, 現在入手可能な情報を効 率的に利用し，即実用に適用できることを条件として， その可能性を検討することにした.

危機管理型防災対策の実現のためには，避難誘導等の 洪水体制への移行判断を正確に行うことが重要となるた め, 今後3 6時間程度先の状況を如何に的確に把握する かが鍵となる. この3〜 6時間程度先の予測雨量としては, 現在, 気象庁メソ数值予報モデル（Meso Spectral Model, 以下，MSMと呼ぶ）の降水量予測值が格子点值（Grid Point Value : GPV) として入手可能であるため, 本研究 では，まず，このMSM降水量予測值の利用可能性につ いて検討し, 次に, MSMで降水量予測值とともに提供 されている各種気象要素そのものあるいは何らかの簡易 な加工を施した気象要素が河川管理上有効な判断情報と なり得ないかの検討を行った.

なお，GPVの河川管理への利用を試みた研究としては,

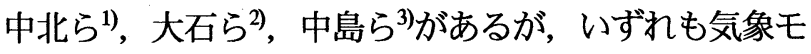
デルの初期条件, 境界条件としてGPVを利用したもので あり, GPVそのものの直接的な利用はされていない.

\section{2. 気象庁メソ数値予報モデル（MSM）GPVの概要}

気象庁メソ数值予報モデルMSMは，現在気象庁が実 施している天気予報のガイダンス資料（予報官が予報時 に使う統計的予測資料）の作成及び降水6時間予報を主 目的として，2001年3月から運用されている. MSMの概 要を表-1に, MSMの予報変数を表-2に示す.

\section{MSM降水量予測值と実績降水量の比較}

前章で紹介したMSM-GPVで提供されている時間降水 量予測值（以下，MSM降水量予測値と呼ぶ） と実績降 水量の比較を行い, 降水量予測值そのものの危機管理型 防災対策への利用可能性について検討した．なお，紙面 の都合上割愛したが，降水量予測值の実績降水量との比 較を行うにあたつては, 降水量以外の気象要素である気 圧，気温についても同様の比較を行い，概ね良好な一致 を示していることを事前に確認した. また, メッシュ単 位の降水量予測值が現時点では河川管理に直接利用でき る程の精度を有していないことはよく言われていること であり，メッシュ単位の評価は意義が少ないと考えられ
表-1 MSMの概要4)

\begin{tabular}{|c|c|}
\hline 項 目 & 内 容 \\
\hline 予報期間 & 18時間（00/06/12/18UTCを初期時刻として1日4回） \\
\hline $\begin{array}{l}\text { 数値計算時の } \\
\text { モテル領域 }\end{array}$ & $\begin{array}{l}\text { ・グリッド数:361×289×40 } \\
\text { ・水平解像度:約 } 10 \mathrm{~km}\end{array}$ \\
\hline $\begin{array}{l}\text { デー夕配信時 } \\
\text { のモデル領域 }\end{array}$ & $\begin{array}{l}\text { - 緯度: } 22.4 \mathrm{~N} \sim 47.6 \mathrm{~N} \\
\text { - 経度:120.0E } 150.0 \mathrm{E} \\
\text { - 等圧面: } 120 \times 124 \times 14 \text { (水平解像度 } 20 \mathrm{~km} \text { ) } \\
\text { - 地表面: } 240 \times 252 \text { (水平解像度 } 10 \mathrm{~km} \text { ) }\end{array}$ \\
\hline 投影座標系 & ランベルト正積方位図法座標 \\
\hline 鉛直座標系 & $\sigma-\mathrm{P}$ ハイブリッド（ $\eta$ 座標系） \\
\hline 側面境界条件 & $\begin{array}{l}\text { • 00UTC,12UTC:12時間前初期値のRSM } \\
\text { • 06UTC,18UTC:6時間前初期值のRSM }\end{array}$ \\
\hline 方程式 & プリミティブ方程式系（静力学近似） \\
\hline 時間積分 & セミインプリシット法 \\
\hline 初期値化 & $\begin{array}{l}\text { 非線形ノーマルモードイニシャリゼーション+レー } \\
\text { ターーアメダス }\end{array}$ \\
\hline 降水過程 & $\begin{array}{l}\text { - Arakawa \& Schbert } \\
\text { - large scale condensation } \\
\text { - convective adjustment } \\
\end{array}$ \\
\hline 接地境界. & モニンーオブコフ相似則 \\
\hline 大気境界 & Level 2 closure + non-local PBL \\
\hline 放射過程 & GSM8911*と同じ手法 \\
\hline 地表面過程 & 3層の温度予測 \\
\hline
\end{tabular}

※ UTC(Coordinated Universal Time):協定世界時

RSM(Regional Spectral Model):気象庁領域数值予報モデル

GSM(Global Spectral Model):気象庁全球数值予報モデル

表-2 MSMの予報変数

\begin{tabular}{|c||c|}
\hline 高 度 & \multicolumn{1}{|c|}{ 予報変数 } \\
\hline \hline 地表面 & 海面更正気圧, 風速, 気温, 相対湿度, 時間降水量, 雲量 \\
\hline 気圧面 & $\begin{array}{l}\text { ジオポテンシャル高度, 風速, 気温, 相対湿度, 鉛直気圧 } \\
\text { 速度 }\end{array}$ \\
\hline
\end{tabular}

るが，本論文の目的がMSM-GPVの河川管理への利用可 能性について調査することであり，そのためには，まず， 降水量予測值が実際にどの程度の精度を有しているのか を確認する必要があると判断されたため, メッシュ単位 の評価をあえて実施するものとした.

\section{（1）MSM降水量予測值と実績降水量の比較条件}

MSM降水量予測値と実䋶降水量の比較条件は以下の とおりである.

\section{a) 比較対象実績降水量}

AMeDAS福岡（北緯 $33^{\circ} 34.8^{\prime}$ ，東経 $130^{\circ} 22.6^{\prime}$ ， 標高3m）における実績降水量を比較対象とした.

b) 比較対象MSM降水量予測值

AMeDAS福岡を含む水平解像度約10kmのメッシュに おけるMSM降水量予測值（予測時間が00/06/12/18UTC の6時間間隔であるため，それぞれの予測時刻の1〜6時 間予測値を使用）とした.

\section{c）比較期間}

九州地方で比較的降水量が多かった2001年6月と 10 月 の2ケ月を比較対象期間とした. なお，2001年6月並びに 10月の気象概要は以下のとおりである. 
6月：19日以降は梅雨前線の影響でまとまった降雨がも たらされており, 特に19〜20日にかけては, 総雨量 230mmにも達し, 警戒水位を越える河川も見られた.

10月 : 低気圧及び台風の影響により5〜7日間隔で降雨が もたらされており，16〜17日にかけては秋雨前線の影響 で, 大分, 宮崎で総雨量 $400 \mathrm{~mm}$ を越える豪雨を記録し ているが, 福岡では総雨量40mm程度である.

\section{（2）MSU降水量予測值と実績降水量の比較}

MSM降水量予測值と実績降水量を(1)に示した条件で 比較した結果は以下のとおりである.

a) ハイエトグラフ

6月と10月の月降水量を, AMeDAS福岡を含むメッ シュのMSM降水量予測值とAMeDAS福岡における実績 降水量とで比較すると表-3に示すとおりとなり，10月に ついてはほぼ同程度の月降水量となっているものの, 6 月については実績降水量の $1 / 3$ 程度の降水量予測値と なっている.

\section{表-3 月降水量比較表}

\begin{tabular}{|c||c|c|}
\hline & 実績降水量 & 降水量予測値 \\
\hline \hline 2001年 6月 & $491 \mathrm{~mm}$ & $166 \mathrm{~mm}$ \\
\hline 2001年10月 & $148 \mathrm{~mm}$ & $141 \mathrm{~mm}$ \\
\hline
\end{tabular}

6月と10月に観測された降雨のうち，それぞれの月の 主要な降雨イベント時におけるAMeDAS福岡を含む メッシュのMSM降水量予測值とAMeDAS福岡の実績降 水量のハイエトグラフを比較したものを図-1に示す。こ れによると，6月，10月ともに精度良く予測できている とは言い難く, 特に6月については, $20 \mathrm{~mm} / \mathrm{hr}$ 以上の比 較的規模の大きな降雨をほとんど予測できていないこと が分かる.
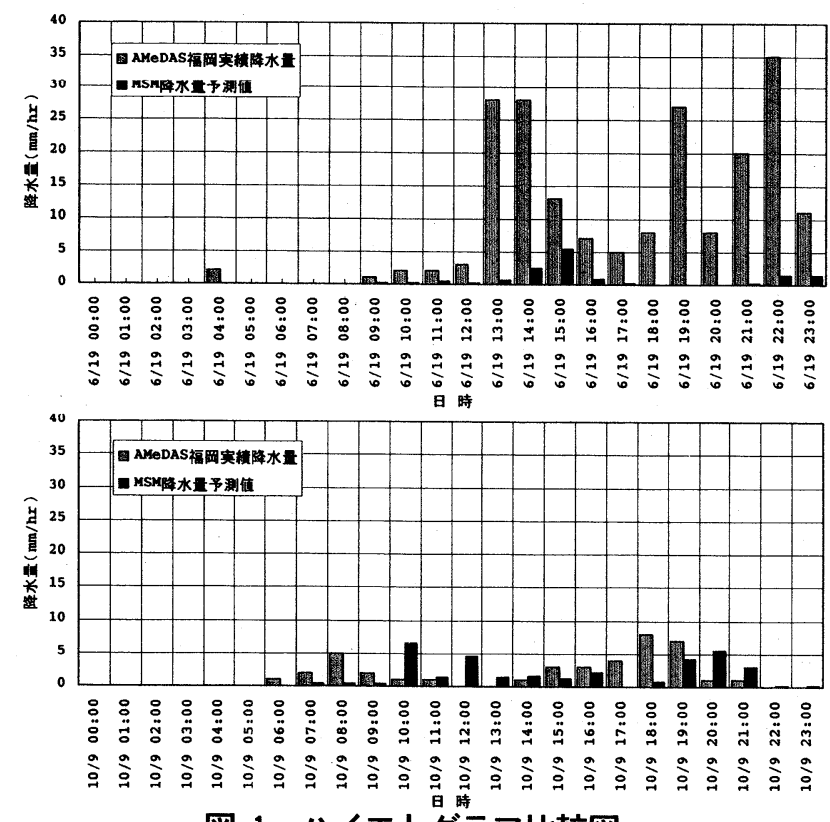

図-1 ハイエトグラフ比較図

\section{b) 相関解析}

MSM降水量予測值と実績降水量との相関性の有無を
定量的に評価するため，相関解析を実施した. なお比較 するMSM降水量予測値については, AMeDAS福岡を含 むメッシュに加え, その周りの24メッシュも対象とした. 算定した各メッシュの相関係数は図-2に示すとおりであ り，6月で0.4程度，10月で0.3程度の相関性が見られた。

また，いずれの月も， AMeDAS福岡を含むメッシュよ りも南側のメッシュで比較的高い相関性を示しているこ とが分かる.

\begin{tabular}{|c|c|c|c|c|c|}
\hline & 82 & 83 & 84 & 85 & 86 \\
\hline \multirow{2}{*}{139} & 0.155 & 0.202 & 0.239 & 0.228 & 0.219 \\
\hline & 0.222 & 0.218 & 0.203 & 0.187 & 0.202 \\
\hline \multirow{2}{*}{140} & 0.196 & 0.245 & 0.304 & 0.327 & 0.303 \\
\hline & 0.220 & 0.205 & 0.214 & 0.236 & 0.245 \\
\hline \multirow{2}{*}{141} & 0.194 & 0.224 & 0.298 & 0.350 & 0.356 \\
\hline & 0.206 & 0.223 & 0.272 & 0.286 & 0.271 \\
\hline \multirow{2}{*}{142} & 0.230 & 0.180 & 0.259 & 0.353 & 0.398 \\
\hline & 0.233 & 0.229 & 0.266 & 0.277 & 0.281 \\
\hline \multirow{2}{*}{143} & 0.418 & 0.356 & 0.356 & 0.398 & 0.436 \\
\hline & 0.283 & 0.306 & 0.295 & 0.280 & 0.298 \\
\hline
\end{tabular}

図-2 相関係数分布図

\section{c) 的中率等}

AMeDAS福岡を含むメッシュのMSM降水量予測值と AMeDAS福岡における実績降水量を的中率, スレット スコア, 見逃し率及び空振り率（算定方法は下記参照） で評価した. なお，的中率等の評価は，全予測時刻予測 值並びに1 6時間後の予測值毎に行うものとし, 間值は いずれも0.1mmとした.

\begin{tabular}{|c|c||c|c|}
\hline \multicolumn{1}{|c|}{ 【的中率等の算定方法】 } \\
\cline { 3 - 4 } \\
\hline \hline
\end{tabular}

全予測時刻予測值について評価した結果は表-4に示す とおりであり，防災対策を行う上で重要な指標である見 逃し率が比較的高い結果となった.

1〜6時間後の予測值毎に評価した結果は図-3に示すと おりであり，これだけでは明確な判断は困難であるが, 概ね2〜3時間後の予測值でスレットスコアが最大となり, それ以降の予測時間では, スレットスコアが低下するに 伴い, 見逃し率, 空振り率が増加する傾向にある.

以上までの結果より, MSM降水量予測值そのものの 危機管理型防災対策への利用については，現時点では困 難であると判断される.

\section{表-4 的中率等評価結果（全予測時刻予測值対象）}

\begin{tabular}{|c||c|c|}
\hline & 2001年 6月 & 2001 年10月 \\
\hline \hline 的中率 & $83.7 \%$ & $88.0 \%$ \\
\hline スレットスコア & $34.1 \%$ & $34.3 \%$ \\
\hline 見逃し率 & $37.5 \%$ & $27.0 \%$ \\
\hline 空振り率 & $57.1 \%$ & $60.7 \%$ \\
\hline
\end{tabular}




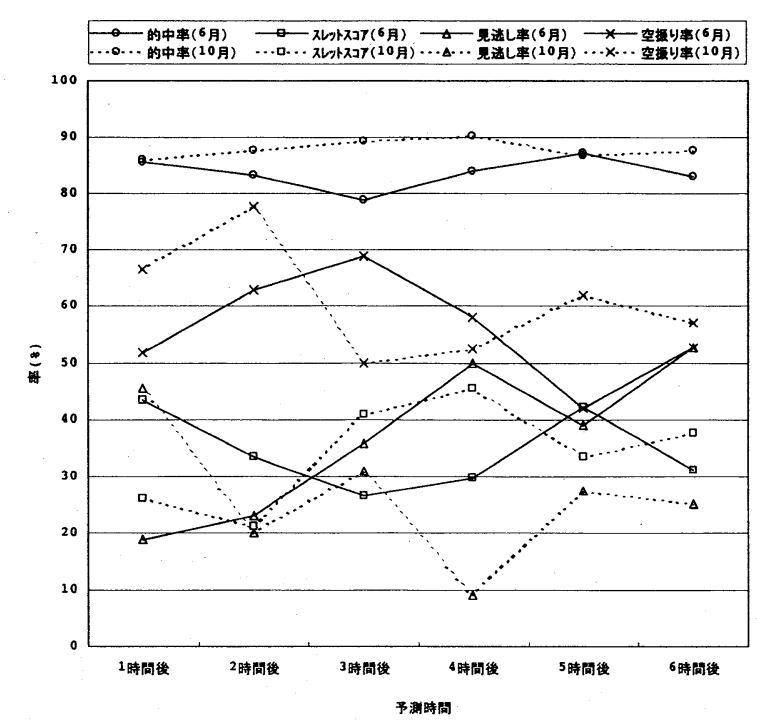

図-3 的中率等評価結果

\section{4. 気象要素と実績降水量の比較}

前章でMSM降水量予測值と実績降水量の比較を行つ たが，危機管理型防災対策を実現する上でMSM降水量 予測值そのものを利用するには問題があることが分かっ た. そこで, MSM降水量予測值の精度向上については, 気象研究者の今後の研究に期待することとし, 即実用と いう河川管理者の立場から, MSM気象要素もしくは MSM気象要素を用いて簡単な処理により得られる加工 気象要素と実績降水量の関係を検討した.

\section{（1）対象としたMSM気象要素}

今回対象としたMSM気象要素は次のとおりである.

(1) 気温 $(T)$

(2) 相対湿度 ( Rh )

(3) 鉛直気圧速度 $(\omega)$

(4) 比湿 $(q)$

(5) 水平収束量 $(\nabla \cdot \mathbf{V})$

(6) 水平比湿収束量 $(\nabla \cdot q \mathbf{V})$

(7) 疑似安定解消凝結水量 $(C)$

$$
\begin{aligned}
& C=C_{c}+C_{s} \\
& C_{c}=\rho \times \delta q_{c} \\
& \delta q_{c}=q_{I}-q_{F s} \times r_{s c} \\
& q_{F s}=0.622 \frac{e\left(T_{F}\right)}{P} \\
& C_{s}=\rho \times \delta q_{s} \\
& \delta q_{s}=\frac{q_{s}(T, p) \times\left(r_{s c}-r\right)}{L} \frac{L L q_{s}(T, p)}{R T^{2}}
\end{aligned}
$$

(8) 疑似安定解消凝結水収束量 $(\nabla \cdot C \mathrm{~V})$

$$
\nabla \cdot C \mathbf{V}=\frac{\partial u C}{\partial x}+\frac{\partial v C}{\partial y}
$$

ここで, $\rho$ は乾燥空気の密度 $\left(\mathrm{kg} / \mathrm{m}^{3}\right), T$ は気温

$\left({ }^{\circ} \mathrm{C}\right), \delta q_{c}$ は各層の不安定状態を解消するときの混合 比の增減量 $(\mathrm{kg} / \mathrm{kg}) ， q_{I}$ は不安定解消前の混合比 $(\mathrm{kg} / \mathrm{kg}) ， r_{s c}$ は $T$ における凝結限界飽和相対湿度 （\%）， $q_{F s}$ は $r_{s c}$ を90\%と仮定して大気を凝結させる ことで不安定を解消させた後の飽和混合比 $(\mathrm{kg} / \mathrm{kg})$, $T_{F}$ は不安定解消後の気温 $\left({ }^{\circ} \mathrm{C}\right), P$ は気圧 $(\mathrm{hPa})$, $e$ は水蒸気圧 $(\mathrm{hPa}), q_{s}$ は気温 $T$ における飽和混合 比 $(\mathrm{kg} / \mathrm{kg}) ， \delta q_{s}$ は過飽和分の混合比 $(\mathrm{kg} / \mathrm{kg}) ， L$ は 単位質量の水蒸気の蒸発潜熱 $\left(2.5 \times 10^{6} \mathrm{~J} / \mathrm{kg}\right), C_{p}$ は大 気定圧比熱 $(1,004.6 \mathrm{~J} / \mathrm{kgK}), R$ は気体定数 $(287.04 \mathrm{~J} / \mathrm{kgK})$ である. また, 本研究において, $C_{c}$ は 不安定解消凝結水量 $(\mathrm{mm}), C_{s}$ は過飽和解消凝結水 量 $(\mathrm{mm})$ と定義した.

\section{（2）MSM気象要素と実績降水量の比較条件}

気象要素と実績降水量の比較条件は次のとおりである.

\section{a) MSM対象領域}

九州周辺を対象とし，27N〜37N，125E〜135E，鉛直 方向 12 層の $40 \times 50 \times 12$ グリッドとした.

\section{b) 比較期間}

2001年6月と10月の各1ヶ月間とし, MSM気象要素は 00/06/12/18UTCにおけるMSMの初期值を使用した.

\section{c）比較対象実績降水量}

MSMグリッド内に存在するAMeDASを用い, 次の5つ の降水量を比較対象実績降水量とした.

- AMeDAS福岡における6時間累積降水量

- 福岡県内AMeDAS（18観測所）における6時間累 積降水量の平均

- 福岡県内AMeDAS（18観測所）における6時間累 積降水量の最大

- 北部九州（福岡, 佐賀, 長崎県）AMeDAS（48観 測所）における6時間累積降水量の平均

- 北部九州（福岡, 佐賀, 長崎県) AMeDAS（48観 測所）における6時間累積降水量の最大

\section{（3）MSM気象要素と実績降水量の比較}

(2)に示す条件で相関係数を算出した. AMeDAS福岡 における6時間降水量について, 算出した相関係数の3次 元分布図を図-4に，また，各気象要素で850hPa面におけ る相関係数の2次元分布図を図-5に示す. 6月の降水は, そのほとんどが梅雨前線によるものであり, 図-5(1)の $\nabla \cdot V, \nabla \cdot q \mathbf{V}$ には，梅雨前線と考えられる北東から南 西にのびる相関の高いエリアが見られる.

次に, 各実績降水量と最も相関性が高いグリッドの相 関係数を表-5に示した. 相関係数の值は-1.0から1.0の範 囲であり，1.0に近ければ『実績降水量が増加すると気 象要素も増加傾向にあるグリッド』，-1.0に近ければ 『実績降水量が増加すると気象要素も減少傾向にあるグ 
リッド』を指す．各気象要素において，正負の相関係数 の最大值が存在するが，表-5では絶対值の大きい方を記 載してあり, 絶対值で 0.7 以を灰色で示している.

これより，6月及び10月ともに各気象要素と最も相関 性が高いのはAMeDAS福岡の実績降水量である。また, 相関性が高い気象要素は, 6 月では $\nabla \cdot \mathbf{V}$ と $\nabla \cdot q \mathbf{V}, 10$ 月は $\omega, \nabla \cdot \mathbf{V}$ 及び $\nabla \cdot q \mathbf{V}$ であり，特に算定時に風速 を使用する気象要素の相関が高い結果となった. また, 本研究で定義した $C$ 及び $\nabla \cdot C \mathrm{~V}$ は，6月は相関が低<, 10月が高い結果となった。これは，6月のCが，福岡で 降雨がもたらされたときには，ほとんど0に近い值と なっていることがその要因である.

\section{表-5（1） 相関係数最大値（2001年6月）}

\begin{tabular}{|c|c|c|c|c|c|}
\hline 要 素 & $\begin{array}{c}\text { AMeDAS } \\
\text { 福 岡 }\end{array}$ & $\begin{array}{ll}\text { 福 } & \text { 岡 } \\
\text { 平 } & \text { 均 }\end{array}$ & $\begin{array}{ll}\text { 福 岡 } \\
\text { 最 大 }\end{array}$ & $\begin{array}{l}\text { 北部九 } \\
\text { 州平均 }\end{array}$ & $\begin{array}{l}\text { 北部九 } \\
\text { 州最大 }\end{array}$ \\
\hline$T$ & 0.46 & 0.32 & 0.34 & 0.30 & 0.37 \\
\hline$R h$ & 0.58 & 0.43 & 0.45 & 0.47 & 0.51 \\
\hline$\omega$ & - 0.67 & -0.65 & -0.57 & -0.59 & 0.19 \\
\hline$q$ & 0.46 & 0.36 & 0.39 & 0.32 & 0.42 \\
\hline$\nabla \cdot \mathbf{V}$ & 0.70 & 0.52 & 0.54 & 0.50 & 0.55 \\
\hline$\nabla \cdot q \mathbf{V}$ & 0.73 & 0.54 & 0.57 & 0.52 & 0.57 \\
\hline$C$ & -0.11 & -0.09 & -0.10 & -0.10 & -0.18 \\
\hline$\nabla \cdot C \mathrm{~V}$ & 0.11 & 0.08 & 0.10 & 0.10 & 0.16 \\
\hline $\begin{array}{l}\text { 絶対値 } \\
\text { の平均 }\end{array}$ & 0.48 & 0.37 & 0.38 & 0.36 & 0.41 \\
\hline
\end{tabular}

表-5（2） 相関係数最大値（2001年10月）

\begin{tabular}{|c|c|c|c|c|c|}
\hline 要 素 & $\begin{array}{l}\text { AMeDAS } \\
\text { 福 岡 }\end{array}$ & $\begin{array}{ll}\text { 福 } & \text { 岡 } \\
\text { 平 均 }\end{array}$ & $\begin{array}{l}\text { 福 } \text { 岡 } \\
\text { 最 大 }\end{array}$ & $\begin{array}{l}\text { 北部九 } \\
\text { 州平均 }\end{array}$ & $\begin{array}{l}\text { 北部九 } \\
\text { 州最大 }\end{array}$ \\
\hline$T$ & 0.59 & 0.58 & 0.61 & 0.54 & 0.54 \\
\hline$R h$ & 0.62 & 0.59 & 0.61 & 0.56 & 0.59 \\
\hline$\omega$ & -0.88 & -0.79 & -0.72 & -0.80 & -0.72 \\
\hline$q$ & 0.56 & 0.54 & 0.57 & 0.48 & 0.48 \\
\hline$\nabla \cdot \mathbf{V}$ & 0.86 & 0.68 & 0.59 & 0.59 & 0.56 \\
\hline$\nabla \cdot q \mathbf{V}$ & 0.88 & 0.72 & 0.61 & 0.63 & 0.60 \\
\hline$C$ & 0.65 & 0.75 & 0.52 & 0.67 & 0.52 \\
\hline$\nabla \cdot C \mathrm{~V}$ & 0.67 & 0.76 & 0.55 & 0.68 & 0.53 \\
\hline $\begin{array}{l}\text { 絶対値 } \\
\text { の平均 }\end{array}$ & 0.68 & 0.65 & 0.59 & 0.60 & 0.57 \\
\hline
\end{tabular}

\section{5. 結 論}

本稿では, 現在, 入手可能な気象庁メソ数值予報モデ ル（MSM）GPVの危機管理型防災対策への利用可能性 について調査した. 今回調查の対象とした降雨イベント の数が少ないため, 今後さらに多くの降雨イベントを対 象に同様の調査を行い確認していく必要があるが, MSM降水量予測值そのもののもしくはMSM気象要素そ

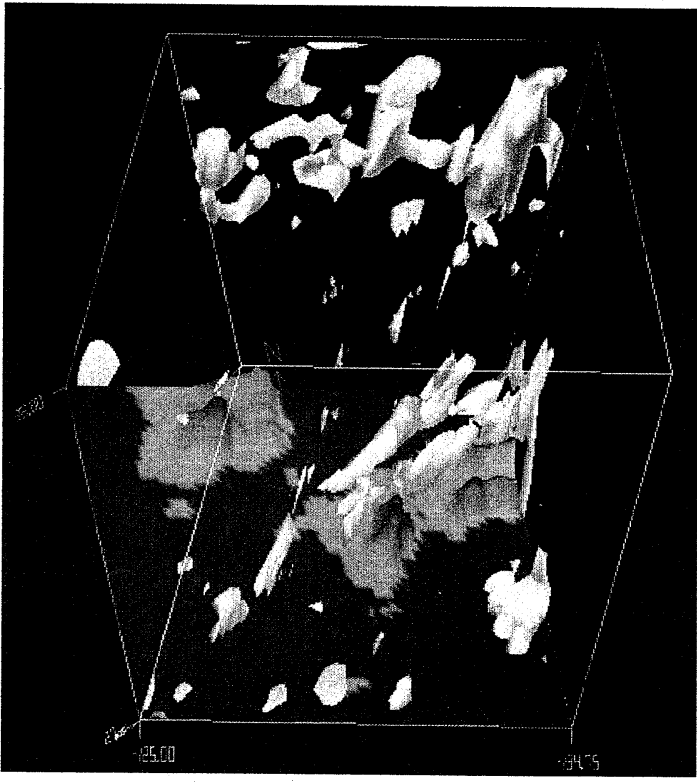

図-4 相関係数の3次元分布図 $(\nabla \cdot q \mathbf{V}, 6$ 月) (相関係数0.4以上の領域を表示)

のものの危機管理型防災対策への利用は現時点では困難 であると考えられた．但し，MSM気象要素を用いて簡 易な加工を施した気象要素の幾つかについては，実績降 水量とのよい相関性が見られたものもあり，将来的には， これらの加工気象要素の危機管理型防災対策への利用可 能性も期待できるが，現時点では，降雨イベントにより 相関性が高い場所が異なる等の特性があり，どの地点の ぞの気象要素に着目すれば降水量を定量的に予測できる かというところまでは特定できないのが現状である，本 稿ではMSM気象要素の格子点値を対象に調査を行った が，これらの気象要素は，実際には3次元の分布形を呈 しており, 今後は, 各気象要素の 2 次元あるいは3次元分 布形と降水量の関係を調べることにより，分布形のパ ターンから降水量を予測する手法の開発を実施していく 予定である.

\section{参考文献}

1） 中北英一・杉本聡一郎・池淵周一・中村徹立・奥田昌 弘・山路昭彦・高棹伥磨 : 3次元レーダーおよびGPVデー 夕を用いた短時間降雨予測手法, 土木学会水工学論文集, 第40巻, pp.303-308, 1996.

2）大石哲 - 舛田直樹 - 池淵周一 : 定性的短時間強雨予測手 法による洪水制御支援手法の開発，土木学会論文集，

No.691, II-57, pp.13-23, 2001.

3） 中島隆信・吉谷純一・金木誠 : メソスケール大気モデル による平成10年 8 月末豪雨の再現計算, 水文・水資源学会 2000 年研究発表会要旨集, pp.134-135, 2000.

4）気象庁編：新しい数值解析予報システム，気象庁予報部， 2000.

(2002. 9. 30受付) 

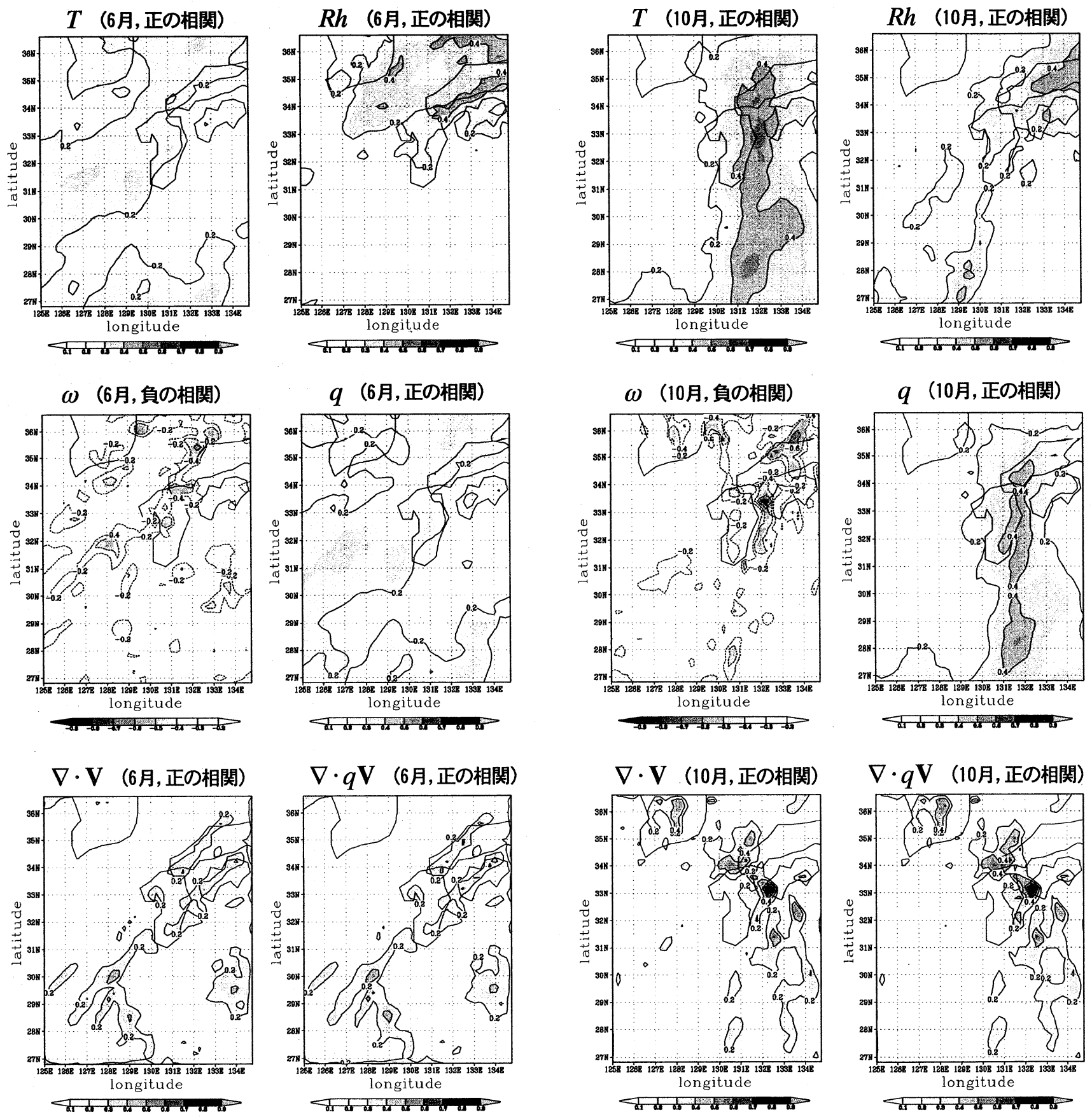

\section{C (6月, 負の相関)}
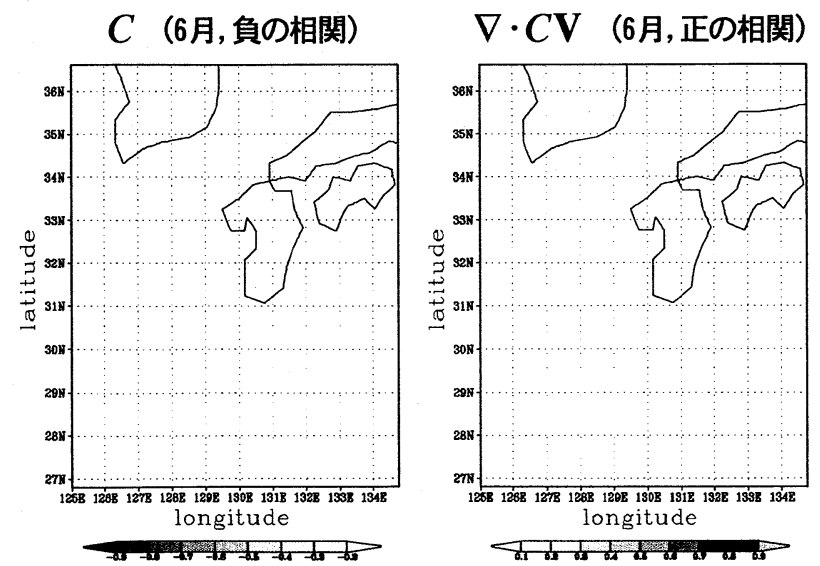

図-5（1）各気象要素とAMeDAS福岡の相関（6月, 850hPa）
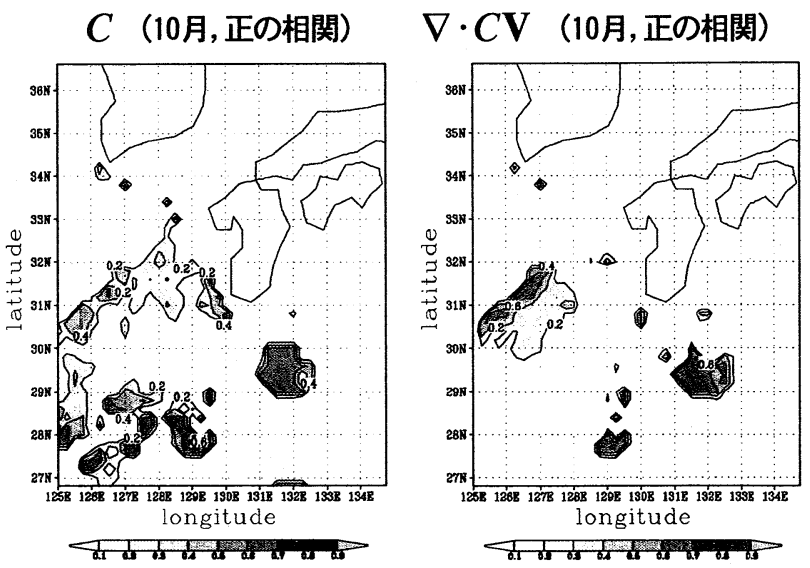

図-5(2) 各気象要素とAMeDAS福岡の相関 $(10$ 月, 850hPa) 